\title{
Online Reservation Abandonment: How to Bridge the Gap between the Original Intention and the Actual Behavior?
}

\author{
Mohamed Nabil Mzoughi, Anissa Negra, Aïcha Habacha
}

MaPReCoB Research Unit, Higher Institute of Management, Sousse University, Sousse, Tunisia.

Email: \{Teachershello, Habacha_aicha\}@yahoo.fr, anissanegra@gmail.com

Received April 17 ${ }^{\text {th }}, 2012$; revised May $1^{\text {st }}, 2012$; accepted May $30^{\text {th }}, 2012$

\begin{abstract}
Online reservation abandonment has not been yet explained by scholars. This research aims to identify key drivers to the issue. It proposes a theoretical framework inspired from behavioral theories particularly from Morrison's Model (1979) stipulating that actions are controlled by intentions, but not all intentions are accomplished. Findings show that online consumer procrastination and website quality encourage online shoppers to intend to drop out an e-reservation and leave the hotel website without culminating the purchase. This study provides hoteliers with insights to improve purchase conversion rates on their own websites.
\end{abstract}

Keywords: Online Reservation Abandonment; Intention-Behavior Discrepancy; Online Consumer Procrastination; Hotel Website Quality

\section{Introduction}

The significant growth of the number of Internet users improved e-commerce in several industries, particularly in hospitality and tourism [1,2]. $70 \%$ of tourists now choose their holiday destination by browsing the Internet [3]. The prevalence of Internet has inevitably changed the booking habits of tourists [4]. Customers can book hotel rooms at anytime, anywhere, and can receive immediate confirmations [5]. However, despite the increasing shares of online booking for hotel rooms, most reservations are still performed through the traditional way [4]. Accordingly, online hoteliers have invested considerable amounts of money and effort in order to entice tourists into visiting their website $[5,6]$. But, getting a person to visit an online site is not enough; visitors are not converted systematically into purchasers. E-shoppers may initiate the checkout process, but leave before completing their purchase. Decision dropout is one of the most commonly reported difficulties to online commerce revenue generation and profitability [7]. With millions of websites competing for attention, some online shoppers are likely to checkout more than 10 websites to make a purchase decision weeks later [8].

Despite the growing body of the literature about the e-reservation, very little attention has been paid to online reservation abandonment. This research aims to study the discrepancy between the intention to book a hotel room and its abandonment. It proposes a theoretical framework that enhances the understanding of the abandonment of online reservations. It investigates the importance of the hotel website and the consumer's characteristics in the explanation of the likelihood to abort the intention to book a hotel room and its abandonment.

Managers need to understand why consumers abort intended purchases and cope with. These understandings can provide insights to hoteliers on how to encourage tourists not to abandon the site when it comes to decide where to book. Information on the perceptions of e-customers of the importance of the overall quality of hotel websites is also provided to hotel managers. This research contributes to helping them make market-oriented decisions relating to the hotel website and online booking.

\section{Research Model}

Intention reflects the individual's likelihood of engaging in the behavior of interest [9]. It measures how hard an individual is willing to take a specific action $[9,10]$. Generally, it is associated with high correspondence with the actual behavior [11]. Models from social psychology such as the Theory of Reasoned Action (TRA) [10], the Theory of Planned Behavior (TPB) $[9,11,12]$ and the Technology Acceptance Model (TAM) [13] have been widely used to explain the consumer decision-making process in traditional and unconventional settings [14-16]. These theories address a positive and a significant rela- 
tionship between individual's intention and actual behavior $[9,13,10]$. The stronger an individual's behavioral intention is, the more likely she/he is to perform the behavior $[9,13,10]$. However, not all intentions are accomplished $[12,17,18]$. Some are abandoned while others are revised to fit changing circumstances $[12,17,18]$. The intention-action gap is "the degree that people follow-up on their original plans" [19]. This phenomenon has been a major concern since the beginning of online shopping. Despite the growth of this latter, the discrepancy between online purchase intention and actual purchase remains [20]. It has been noticed that there are two possible online shopping behaviors in response to an e-shopping intention: online purchase and purchase abandonment. An individual with a high intention to engage in online decision process may change his mind and not culminate the transaction $[21,22]$. He is willing to abort the intended transaction before checkout [22]. Thus, e-shoppers intending to book a hotel room over the Internet are expected to abandon this original intention.

H1: There is a gap between the original intention and the actual behavior.

In order to explain the divergence between intention and action, Morrison [18] is the first to propose intermediate links between the original intention and the actual purchase. Customers may shift from an intention to a new true intention. At any time, each person has several conscious and unconscious intentions, to which it is assigned varying levels of both importance and relevance to the current context [23]. In a web-based purchase environment, a customer with a purchasing intention unconsciously has the intention to abort this first intention when he decides to visit another website. Consumers' intentions may change over time $[9,22,24]$ due to the information content of competitors' websites and other stimuli encountered while browsing [25]. Therefore, it is expected that a traveler with high intention to e-book a hotel room convert to a traveler with the intention to abort an online hotel room reservation.

H1a: Online intentions change.

Based on the intention-behavior relationship proposed by the behaviorist models, we argue the intention to abort the online reservation, is a predictor of the actual abandonment of the reservation. Thus:

H1b: The intention to abort the online reservation positively influences its abandonment.

The gap between intention and behavior has been attributed to individual [12,26,27], situational factors [20, $26]$ and time [12,18,24,28]. Cote and Wong [24] have indicated that intention-behavior correlation decreases as the time interval between them increases. Consumers may postpone voluntarily or involuntarily purchasing a product $[29,30]$. The longer the period of the delay, the more they are likely to abandon their original intention [18]. This is especially true for procrastinators [29,31-34]. These latter chronically delay their planned purchases. They spend longer time gathering information, evaluating and comparing available alternatives, but, without a good reason. Negra et al. [35] and Mzoughi et al. [36] extended Darpy's researches on procrastination from the traditional to the Internet context to explore online consumer procrastination. In contrast to prior studies, the researchers define the concept as the purposive and rational tendency to delay the accomplishment of a planned purchase over the Internet. It is the wise predisposition to postpone decisions in waiting for additional information (about the website, prices, products, security of the transaction and so forth) to be available and to maximize the likelihood of having the best deal [37]. E-procrastinators are deal-prone and rational consumers. They perceive a higher value of the product when it is in sale and meticulously search and analyze all relevant information while developing their purchase intentions $[35,36]$. This procedure can unintentionally lead to the abandonment of the original intention while visiting competing sites. Hence, we propose that e-procrastination explains the emergence of a new intention: the intention to abort the started transaction. Thus, we propose that:

P1: Online procrastination is positively associated with the intention to abort an online hotel room reservation.

Using click-stream data analyses, $\mathrm{Li}$ and Chatterjee [21] pointed out that website quality is a relevant predictors of online decision dropout. Website quality is better considered through information content, ease of use, design, security and privacy, usefulness [38]. The website informational content should enable visitors to clarify their ambiguity, improve their understanding of issues $[39,40]$ and ameliorate purchase decisions [41,42]. The website design refers to how information is displayed on a shopping website [41]. A number of design elements can be used to communicate the content of a website: the quality and the size of images, the animation and/or audio, number of words per line, color and size of characters [43]. Online transaction security and privacy refers to the confidentiality, integrity, authentication, and non repudiation of the personal data of the online buyer [40]. Perceived website ease of use is the degree to which Internet users believe that the amount of effort needed to use a website is free or low" [4]. Perceived usefulness is "the degree to which users consider that the use of a specific IT improves their results” [13,39]. Website characteristics affect significantly the probability of shopping from the visited site [41]. It is a double added sword. Although they help online shoppers in their purchasing process steps by providing them with more convenience 
and more privacy [45], they can also inhibit information search, cause interruptions, diversion and abandonment of the online shoppers original goals [21]. Accordingly,

H2: Low website quality is passively associated to the intention to abort an online hotel room reservation (see Figure 1).

\section{Method}

In order to validate the research model, a scenario methodology using an online survey method is performed. This method has the advantage of closely simulating the real word at low cost [46]. The investigation was conducted online using an existing hotel website: Marhabahotels.com.tn. According to Harris and Goode [47], focusing on one online vendor allows a better appreciation of the investigated phenomenon and leads to insights that are ignored when studying many suppliers. Marhaba hotels website includes 12 hotels. The chain recently adopted online reservation.

Respondents were first asked to answer questions about online procrastination. Then, they were assigned to simulate making a purchase decision over the Marhaba hotels website before answering the question about their intentions, the website quality, and their final decision.

Concepts were assessed using scales and measures drawn from existing literature. Online consumer procrastination was assessed by a 5-item scale proposed by Negra [37]. It includes both online rationality and online deal-proneness. The intention to abort an online hotel room reservation was measured using 6 items proposed by Cho [22]. The information quality, the website design, the security and privacy and the ease of use items were drawn from the NetQual scale developed by Bressoles [48]. The usefulness of the website was assessed using the instrument proposed by Davis [13]. Online reservation abandonment was measured Matzler et al.'s scale [49]. All scales were rated on a seven-point scale ranging from (1) strongly disagree to (7) strongly agree.

The questionnaire was administered to a sample of 1224 respondents mostly ranging in age from 40 years to more than 50 years $(46.1 \%) .57 .3 \%$ are female. Approximately $42 \%$ of the respondents hold the Bachelor's degree. $33.2 \%$ of them are British, slightly higher than $17 \%$ of the respondents are German, around $11 \%$ are Russian and nearly $10 \%$ are French. The majority of the sample (77.2\%) is familiar with Internet, online shopping and e-reservation.

\section{Results}

In order to investigate the gap between the original intention and online reservation abandonment, descriptive analyses were undertaken. Results show that $37.1 \%$ of the 1224 respondents changed their minds after visiting the website and $53.3 \%$ of the 1224 respondents abandoned their first intention and left the website without booking a room (see Table $\mathbf{1}$ ).

Linear regressions were employed to examine the relationship between the intention to abort an online transaction and the purchase abandonment. The results support the hypothesis H1b. The intention to abort an online transaction significantly affects purchase abandonment $(\mathrm{F}=1067.655, \mathrm{p}<0.001)$.

Findings also show that the online deal proneness ( $\beta \mathrm{s}$ $=0.239, \mathrm{p}<0.001)$ and the online rationality $(\beta \mathrm{s}=0.185$, $\mathrm{p}<0.001)$ are important determinant of the intention to abort an online transaction. As predicted, this latter was also found to be explained by security and information. Usefulness, EOU and design have no significant direct

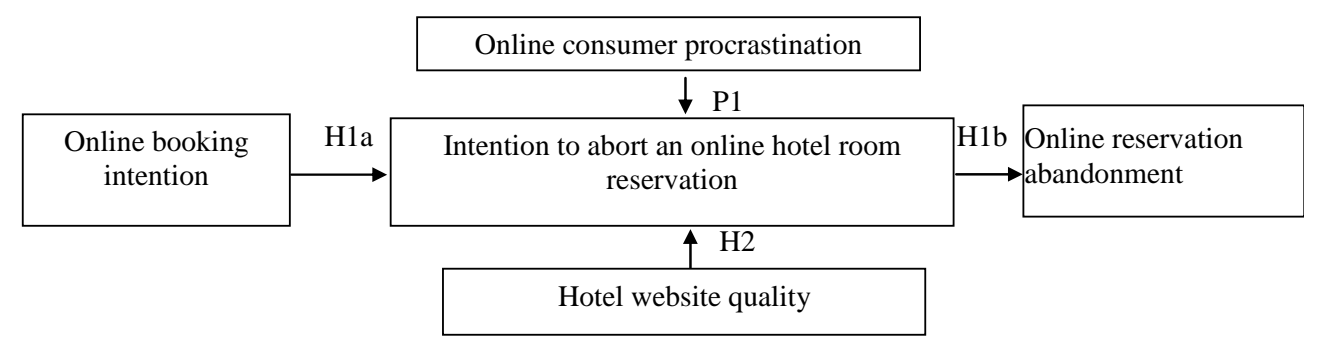

Figure 1. Online reservation abandonment model.

Table 1. Online reservation abandonment rates.

\begin{tabular}{cccccc}
\hline & \multicolumn{2}{c}{ Intention } & \multicolumn{2}{c}{ Behavior } \\
\cline { 2 - 6 } & Original intention* & $\begin{array}{l}\text { Individuals with intention } \\
\text { to abort the intended transaction }\end{array}$ & $\begin{array}{l}\text { Individuals with } \\
\text { intention to buy }\end{array}$ & $\begin{array}{l}\text { Individuals that abandoned } \\
\text { the purchase }\end{array}$ & $\begin{array}{l}\text { Individuals that } \\
\text { purchased }\end{array}$ \\
\hline Frequency & 1224 & 453 & 771 & 655 & 569 \\
$\%$ & 100 & 37.1 & 62.9 & 53.5 & 46.5 \\
\hline
\end{tabular}


effect on the intention to abort an online transaction.

\section{Conclusions}

The purpose of this study is to predict the abandonment of online hotel room reservations. It proposes an integrated framework based on the extension of Morrison's model (1979). Results lend credibility to the significance of the impact of the bad informational content of the website and the lack of security/privacy on the intention to abort the intended e-reservation. Users show a predisposition to abort the intended online reservation when they do not appreciate the website and when they are concerned about losing money while transacting with the hotel. Accordingly, hoteliers would enhance the probability to culminate to the hotel room reservation by providing potential guests with relevant and significant information with regard to the country, the place to visit and the hotel products and services. It is also imperative to make the guest positive about the security of the online transaction and the exhibition of their personal data. Otherwise, potential buyers may convert into non buyers. Results revealed that the investigated hotel website is poor in information and risky, but not complicated, futile, and unprofessionally designed. This could explain the reason why the usefulness, the ease of use and the design of the website have no significant impact on the intention to abort the intended e-reservation.

Marketing literature on intention-behavior discrepancy has demonstrated that this issue is not a random error. It results of different forces that take place between intention and behavior. In addition to measurement issues, several researchers have hypothesized that inconsistencies in intentions can also be attributed to individual and situational differences as well as to delay in consumer decision making. So, we proposed that online consumer procrastination enhances the intention to abort an online hotel room reservation. This research provided empirical evidence to this proposition. In order to convert online consumer procrastinators into online purchasers, it is first of all essential to identify them. Online procrastinators are rational and deal-prone online shoppers. They postpone online purchases in order to gather additional information and to maximize the probability of having the best deal. In order to identify them, Marhaba hotels may use the clickstream data analysis. Because serfer log files record the visitor's ID, it is possible to distinguish between browsers, purchasers and e-procrastinators. It is then suggested to provide the website vistors with full, detailed and clear information. Hoteliers should finally create, launch and adjust personalized web campaigns to target online procrastinators [36]. They could put into practice viral marketing strategies by delivering email campaigns that highlight relevant offers likely to moti- vate online procrastinators to take immediate reservations on the hotel website. Deadlines, competitive prices and full information about the hotel and its services should be emphasized.

This research is subject to some limitations that should be taken into consideration in interpreting the findings. The first one is associated with the sample. Real tourists coming from different nationalities answered the survey. The results could vary according to the customer's cultural background. The second limitation regards some other important antecedents of the issue that were not included in this study, such as negative emotions and past behavior.

\section{Acknowledgements}

The authors would like to thank Slim Akrout, ex general manager of Salem and Royal Salem Marhaba hotels, for his precious help in administering the questionnaire.

\section{REFERENCES}

[1] J. K. Lee and A. M. Morrison, “A Comparative Study of Web Site Performance,” Journal of Hospitality and Tourism Technology, Vol. 1, No. 1, 2010, pp. 50-67. doi:10.1108/17579881011023016

[2] R. Chu, "What Online Hong Kong Travelers Look for on Airline/Travel Websites?” International Journal of Hospitality Management, Vol. 20, No. 1, 2001, pp. 95-100. doi:10.1016/S0278-4319(00)00046-3

[3] S. Tletli, “Tunisia to Boost Online Presence,” Travel and Tourism News Middle East, TTN, 2010. http://www.ttnworldwide.com/articles.aspx?id=1405\&arti $\mathrm{d}=9994$

[4] R. Law and C. Cheung, "A Study of Perceived Importance of the Overall Website Quality of Different Classes of Hotels," International Journal of Hospitality Management, Vol. 25, No. 3, 2006, pp. 525-531. doi:10.1016/j.ijhm.2005.03.001

[5] T. Chung and R. Law, "Developing a Performance Indicator for Hotel Website,” International Journal of Hospitality Management, Vol. 22, No. 1, 2003, pp. 119-125. doi:10.1016/S0278-4319(02)00076-2

[6] A. M. Morrison, S. Taylor, A. J. Morrison and A. D. Morrison, "Marketing Small Hotels on the World Wide Web," Information Technology and Tourism, Vol. 2, No. 2, 1999, pp. 97-113.

[7] A. Gutzman, "The Truth behind Shopping Cart Abandonment Rates,” 2000.

www.ecommerce-guide.com/solutions/technology/article. php/448381

[8] ScanAlert, “A New Era of Digital Window Shopping: From Shopping Cart Abandonment to Purchase,” 2005. http://www.webhostgear.com/shopping_habits.pdf

[9] I. Ajzen, "The Theory of Planned Behavior," Organizational Behavior and Human Decision Processes, Vol. 50, 
No. 2, 1991, pp. 179-211. doi:10.1016/0749-5978(91)90020-T

[10] I. Ajzen and M. Fishbein, "Understanding Attitudes and Predicting Social Behavior,” Prentice-Hall, Englewood Cliffs, 1980.

[11] I. Ajzen, “Attitudes, Personality and Behavior,” Open University Press, Milton Keynes, 1988.

[12] I. Ajzen, "From Intentions to Actions: A Theory of Planned Behavior, in Action Control: From Cognition to Behavior,” Springer, Heidelberg, 1985.

[13] F. D. Davis, "Perceived Usefulness, Perceived Ease of Use, and User Acceptance of Information Technology," MIS Quarterly, Vol. 13, No. 3, 1989, pp. 319-340. doi:10.2307/249008

[14] L. Zhou, L. Dai and D. Zhang, "Online Shopping Acceptance Model: A Critical Survey of Consumer Factors in Online Shopping," Journal of Electronic Commerce Research, Vol. 8, No. 1, 2007, pp. 41-63.

[15] C. M. K. Cheung, G. W. W. Chan and M. Limayem, “A Critical Review of Online Consumer Behavior: Empirical Research,” Journal of Electronic Commerce in Organizations, Vol. 3, No. 4, 2005, pp. 1-19.

[16] P. A. Pavlou, "Consumer Acceptance of Electronic Commerce: Integrating Trust and Risk with the Technology Acceptance Model," International Journal of Electronic Commerce, Vol. 7, No. 3, 2003, pp. 69-103.

[17] A. C. Bemmaor, "Predicting Behavior from Intention-toBuy Measures: The Parametric Case,” Journal of Marketing Research, Vol. 32, No. 2, 1995, pp. 176-191. doi:10.2307/3152046

[18] D. G. Morrison, "Purchase Intentions and Purchase Behavior,” Journal of Marketing, Vol. 43, No. 2, 1979, pp. 65-74. doi:10.2307/1250742

[19] P. Steel, “The Nature of Procrastination,” 2003. www.haskayne.ucalgary.ca/research/media/2003_07.pdf

[20] S. Kim and S. Park, "A Study of Decision Factors for Purchase Intention at the Electronic Commerce,” Journal of Consumer Studies, Vol. 10, No. 3, 1999, pp. 45-66.

[21] S. Li and P. Chatterjee, "Shopping Cart Abandonment at Retail Websites-A Multi-stage Model of Online Shopping Behavior,” 2005

http://elab.vanderbilt.edu/Research_papers/

[22] J. Cho, "Likelihood to Abort an Online Transaction: Influences from Cognitive Evaluations, Attitudes, and Behavioral Variables," Information and Management, Vol. 41, No. 7, 2004, pp. 827-838. doi:10.1016/j.im.2003.08.013

[23] A. V. Gershman, J. F. McCarthy and A. E. Fano, "Situated Computing: Bridging the Gap between Intention and Action," Proceedings of the Third International Symposium on Wearable Computing (ISWC '99), San Francisco, 18-19 October 1999, pp. 3-9. doi:10.1109/ISWC.1999.806635

[24] J. A. Cote and J. K. Wong, "The Effects of Time and Situational Variables on Intention-Behavior Consistency," Advances in Consumer Research, Vol. 12, 1985, pp. 374377.
[25] A. Montgomery, S. Li, K. Srinivasan and J. C. Liecht, "Modeling Online Browsing and Path Analysis Using Clickstream Data," Marketing Science, Vol. 23, No. 4, 2004, pp. 579-597. doi:10.1287/mksc.1040.0073

[26] I. Ajzen, T. C. Brown and F. Carvajal, "Explaining the Discrepancy between Intentions Andactions: The Case of Hypothetical Bias in Contingent Valuation," Personality and Social Psychology Bulletin, Vol. 30, No. 9, 2004, pp. 1108-1121. doi:10.1177/0146167204264079

[27] L. F. Jamieson, “An Investigation of the Relationship between Purchase Intention and Trial Behavior," Ph.D. Thesis, The University of Texas, Dallas, 1986.

[28] V. G. Morwitz, J. H. Steckel and A. Gupta, "When Do Purchase Intentions Predict Sales?” Journal of Forecasting, Vol. 23, No. 3, 2007, pp. 347-364. doi:10.1016/j.ijforecast.2007.05.015

[29] D. Darpy, "Consumer Procrastination and Purchase Delay,” Proceeding of 29th Annual Conference EMAC, Rotterdam, 23-26 May 2000.

[30] E. A. Greenleaf and D. R. Lehmann, "Reasons for Substantial Delay in Consumer Decision Making," Journal of Consumer Research, Vol. 22, No. 2, 1995, pp. 186-199. doi:10.1086/209444

[31] D. Darpy, "Le Report d'achat Expliqué par le Trait de Procrastination et le Potentiel de Procrastination," Recherche et Applications en Marketing, Vol. 17, No. 2, 2002, pp. 1-24.

[32] D. Darpy, "Importance de la Procrastination dans le Processus de Décision d'achat," Communication au Congrès de l'Association Française de Marketing, Montréal, 2000.

[33] D. Darpy, "Une Variable Médiatrice du Report d'achat: La Procrastination,” Thèse de Doctorat en Sciences de Gestion, Université Paris Dauphine, Paris, 1999.

[34] D. Darpy, “Une Variable Médiatrice du Report d’achat: La Procrastination," Actes du 13ème Congrès de l'Association Française de Marketing, Toulouse, 1997.

[35] A. Negra, N. Mzoughi and O. Bouhlel, "E-Procrastination: A Netnographic Approach,” Journal of Customer Behavior, Vol. 7, No. 2, 2008, pp. 103-119. doi:10.1362/147539208X325894

[36] N. Mzoughi, K. Garrouch, O. Bouhlel and Negra, “Online Procrastination: A Predictive Model,” Journal of Internet Business, 2007. http://jib.debii.curtin.edu.au/iss04_mzoughi.pdf

[37] A. Negra, "Online Purchase Abandonment: Antecedents and the Role of E-Procrastination in the Discrepancy between Intention and Behavior, Investigation in the Hospitality Industry,” Ph.D. Thesis, Tunis University, Tunis, 2011.

[38] B. Bai, R. Law and I. Wen, "The Impact of Website Quality on Customer Satisfaction and Purchase Intentions: Evidence from Chinese Online Visitors," International Journal of Hospitality Management, Vol. 27, No. 3, 2008, pp. 391-402. doi:10.1016/j.ijhm.2007.10.008

[39] B. Hernández, J. Jiménez and M. J. Martín, "Key Website Factors in E-Business Strategy," International Journal of 
Information Management, Vol. 29, No. 5, 2009, pp. 362371. doi:10.1016/j.ijinfomgt.2008.12.006

[40] Y. H. Chen, I. C. Hsu and C. C. Lin, "Website Attributes that Increase Consumer Purchase Intention: A Conjoint Analysis,” Journal of Business Research, Vol. 63, No. 919, 2009, pp. 1007-1014. doi:10.1016/j.jbusres.2009.01.023

[41] X. Zhang, V. R. Prybutok, S. Ryan and R. Pavur, "A Model of the Relationship among Consumer Trust, Web Design and User Attributes," Journal of Organizational and End User Computing, Vol. 21, No. 2, 2009.

[42] T. Ahn, S. Ryu and I. Han, "The Impact of Web Quality and Playfulness on User Acceptance of Online Retailing," Information and Management, Vol. 44, No. 3, 2007, pp. 263-275. doi:10.1016/j.im.2006.12.008

[43] D. E. Rosen and E. Purinton, "Website Design: Viewing the Web as a Cognitive Landscape,” Journal of Business Research, Vol. 57, No. 7, 2004, pp.787-794. doi:10.1016/S0148-2963(02)00353-3

[44] S. Rotchanakitumnuai, "Exploring the Antecedents of Electronic Service Acceptance: Evidence from Internet Securities Trading," Proceedings of the Fourth International Conference on eBusiness, Bangkok, 19-20 Novem- ber 2005, pp. 121-126.

[45] C. Ranganathan and S. Ganapathy, "Key Dimensions of Business-to-Consumer Web Sites,” Information and Management, Vol. 39, No. 6, 2002, pp. 457-465. doi:10.1016/S0378-7206(01)00112-4

[46] K. R. Jespersen, “Applying a Behavioural Simulation for the Collection of Data," The Electronic Journal of Business Research Methodology, Vol. 3, No. 2, 2005, pp. 141148.

[47] L. C. Harris and M. H. Goode, "The Four Levels of Loyalty and the Pivotal Role of Trust: A Study of Online Service Dynamics,” Journal of Retailing, Vol. 80, No. 2, 2004, pp. 139-158. doi:10.1016/j.jretai.2004.04.002

[48] G. Bressolles, "La Qualité de Service Electro-Nique: NetQual. Proposition d'une échelle de Mesure Appliquée aux Sites Marchands et Effets Modérateurs,” Recherche et Applications en Marketing, Vol. 21, No. 3, 2006, pp. 19-45.

[49] K. Matzler, M. Waiguny and J. Fuller, "Spoiled for Choice: Consumer Confusion in Internet-Based Mass Customization,” Interactive Marketing, Vol. 3, No. 3, 2007, pp. 718. 